\title{
Strategies to Improve Service Quality with House of Quality at Hotel X Surabaya
}

\author{
Ninnasi Muttaqi'in, Puspandam Katias \\ Nahdlatul Ulama Surabaya University \\ e-mail: puspandam@unusa.ac.id,m.ninnasi@unusa.ac.id
}

\begin{abstract}
Service that can satisfy consumers is the main key for service companies to be able to survive and develop their business. Because service is an intangible product, it requires maximum effort for service providers to be able to obtain satisfactory value from consumers. Understanding consumer needs and trying to meet consumer expectations as best as possible is one way to improve service quality. Hotel is one of the service providers in the tourism and business sector, where at this time hotel service is a critical service in its contribution to the tourism business. This research was conducted at a hotel in Surabaya. Surabaya is one of the metropolitan cities in Indonesia, where service providers have been competing fiercely and continue to innovate in providing services. This is also supported by the characteristics of the city of Surabaya as a trading city, so that it always requires complex services to meet consumer expectations. Therefore, it is very important to improve service quality through the formulation of the right strategy. In this research, it will be known what are the priorities of customers in choosing hotels, hotel service conditions, and hotel internal responses. The research method used in this study is divided into several stages, namely: problem identification, questionnaire creation and distribution, data processing, and the preparation of the House of Quality (HoQ). The data collection method used was a survey method with a questionnaire instrument, while the data analysis technique used was the House of Quality Matrix (HoQ) method as a representation of the Quality Function Deployment (QFD) method where the QFD function was to show how the quality attribute efforts would be derived as an effort to meet customer needs in other words serves to determine what will satisfy customers and translate their customer desires into designed target.
\end{abstract}

Keywords: house of quality, matrix house of quality, quality function deployment

\section{INTRODUCTION}

Hotels not only compete with other hotels, but also have other competitors in similar fields such as inns, leased apartments, meetinghouses, and the like (Ariana, 2018; Arja, 2019; Fitria, 2019; Hakam, 2019). With the increasing number of similar hotel and lodging services, there are many choices for consumers to use tourism services according to consumer desires. This can cause consumers who are dissatisfied with the services of a tourism service provider to move places and use other hospitality and services industries (Kusumaningtyas, 2019; Karya, 2016; Mahanani, 2016; Putri, 2015). As previ- ously explained that consumers can be used as a source of information, if these consumers spread information about their dissatisfaction with other consumers, more and more consumers will leave and not use the previous hospitality and services industries. This causes huge losses for the company.

This study raises the problem of the response and what factors are the priority of customer expectations in choosing hotel $\mathrm{X}$ Surabaya, and aims to determine the service conditions of hotel $\mathrm{X}$ in Surabaya from the customer's perspective. The expected contribution is to provide information that can be used as the manager of $\mathrm{X}$ hotel in Surabaya in 
making policies to improve the quality of service at $\mathrm{X}$ hotel in Surabaya. Based on this explanation, research is needed on "Strategies for Improving Service Quality with the House of Quality at Hotel X Surabaya.”

\section{RESEARCH METHODOLOGY}

This research begins with a preliminary survey, namely making observations in the field about hotel $\mathrm{X}$ in Surabaya, then proceed with secondary data searches about hotel $\mathrm{X}$ in Surabaya through collecting documents from the management of hotel $\mathrm{X}$ in Surabaya, after finding the problems that exist at hotel $\mathrm{X}$ in Surabaya. After conducting a literature review (Katias, 2018) then compiling research instruments and data collection techniques and data analysis techniques used to build the House of Quality matrix, the data obtained from the results of distributing questionnaires is processed and analyzed using the house of quality (HoQ) matrix method as a representation from the quality function deployment (QFD) method (Xie, 2003) where the quality function deployment (QFD) function is to show how the quality attribute effort will be derived as an effort to meet customer needs in other words it functions to determine what will satisfy customers and translate customer desires. their inclusion into target design (Heizer and Render, 2013)

\section{RESULT AND DISCUSSION}

The questionnaire was distributed to 100 guests of Hotel X Surabaya. It was found that the number of female respondents was more than male respondents. The number of female respondents was $76 \%$ and male respondents were $24 \%$. While the number of respondents based on age $25-45$ years was $40.00 \%$ dominant. While the jobs of the majority of respondents are 60 private employees, $15 \%$ are selfemployed, while $10 \%$ are civil servants.

Gap (GAP) between realities and expectations of service quality attributes.

Table 1 Tangible Aspect

\begin{tabular}{|c|l|l|c|c|c|}
\hline No & \multicolumn{1}{|c|}{ Aspect } & \multicolumn{1}{c|}{ Statement } & Reality & Expectation & Gap \\
\hline 1 & Tangible & $\begin{array}{l}\text { Hotel in gooed } \\
\text { conditions }\end{array}$ & 2,64 & 3,74 & $-1,10$ \\
\hline 2 & Tangible & $\begin{array}{l}\text { The hotel equipment } \\
\text { (facilities and } \\
\text { infrastructure) are very } \\
\text { complete. }\end{array}$ & 2,58 & 3,75 & $-1,17$ \\
\hline 3 & Tangible & $\begin{array}{l}\text { The information system } \\
\text { and instructions at the } \\
\text { hotel are clear. }\end{array}$ & 2,74 & 3,79 & $-1,05$ \\
\hline 4 & Tangible & Staff grooming & 2,39 & 3,76 & $-1,37$ \\
\hline 5 & Tangible & $\begin{array}{l}\text { The availability of } \\
\text { adequate parking for } \\
\text { guests }\end{array}$ & 2,80 & 3,78 & $-0,98$ \\
\hline 6 & Tangible & $\begin{array}{l}\text { Hospitality of } \\
\text { receiptionis }\end{array}$ & 2,68 & 3,77 & $-1,09$ \\
\hline & & $\begin{array}{l}\text { Complete supporting } \\
\text { facilities: lobby, coffee } \\
\text { shop, restaurant online } \\
\text { application, etc.) }\end{array}$ & 2,58 & 3,79 & $-1,21$ \\
\hline
\end{tabular}

\section{Table 2 Empathy Aspect}

\begin{tabular}{|c|l|l|c|c|c|}
\hline 1 & Emphaty & $\begin{array}{l}\text { Petugas peduli akan } \\
\text { keinginan tamu }\end{array}$ & 2,46 & 3,74 & $-1,28$ \\
\hline 2 & Emphaty & $\begin{array}{l}\text { Petugas cepat } \\
\text { menanggapi keluhan } \\
\text { tamu }\end{array}$ & 2,51 & 3,77 & $-1,26$ \\
\hline 3 & Emphaty & $\begin{array}{l}\text { Menjaga hubungan baik } \\
\text { kepada konsumen tamu }\end{array}$ & 2,60 & 3,72 & $-1,12$ \\
\hline 4 & Emphaty & $\begin{array}{l}\text { Pengertian petugas } \\
\text { terhadap kebutuhan } \\
\text { yang penting bagi tamu }\end{array}$ & 2,70 & 3,75 & $-1,05$ \\
\hline 5 & Emphaty & $\begin{array}{l}\text { Jam pelayanan yang } \\
\text { sesuai dengan kebutuhan } \\
\text { tamu }\end{array}$ & 2,64 & 3,72 & $-1,08$ \\
\hline 6 & Emphaty & $\begin{array}{l}\text { Kesediaan petugas } \\
\text { mengucapkan salam } \\
\text { sebelum dan sesudah } \\
\text { melayani tamu. }\end{array}$ & 2,62 & 3,76 & $-1,14$ \\
\hline
\end{tabular}

Table 3 Responsiveness Aspect

\begin{tabular}{|c|l|l|c|c|c|}
\hline 1 & Responsiveness & $\begin{array}{l}\text { Responsive in solving } \\
\text { problems with guest } \\
\text { complaints }\end{array}$ & 2,58 & 3,79 & $-1,21$ \\
\hline 2 & $\begin{array}{l}\text { Ability to provide } \\
\text { services quickly and } \\
\text { correctly (Innovative in } \\
\text { communication) }\end{array}$ & 2,73 & 3,75 & $-1,02$ \\
\hline 3 & Responsiveness & $\begin{array}{l}\text { Officers can cooperate } \\
\text { with guests }\end{array}$ & 2,68 & 3,72 & $-1,04$ \\
\hline 4 & Responsiveness & $\begin{array}{l}\text { Willingness of officers } \\
\text { to help guests respond } \\
\text { to complaints }\end{array}$ & 2,62 & 3,78 & $-1,16$ \\
\hline 5 & Responsiveness & $\begin{array}{l}\text { The staff takes the time } \\
\text { to answer guest } \\
\text { questions }\end{array}$ & & & \\
\hline
\end{tabular}


Table 4 Reliability Aspect

\begin{tabular}{|c|l|l|c|c|c|}
\hline 1 & Reliability & $\begin{array}{l}\text { The service ability of } \\
\text { officers can be trusted }\end{array}$ & 2,79 & 3,76 & $-0,97$ \\
\hline 2 & Reliability & $\begin{array}{l}\text { Hospitality service in } \\
\text { serving guests }\end{array}$ & 2,73 & 3,74 & $-1,01$ \\
\hline 3 & Reliability & $\begin{array}{l}\text { Consistency of service } \\
\text { time (timeliness of } \\
\text { opening and closing } \\
\text { hotels) }\end{array}$ & 2,70 & 3,77 & $-1,07$ \\
\hline 4 & Reliability & $\begin{array}{l}\text { Fulfillment of promised } \\
\text { services }\end{array}$ & 2,68 & 3,76 & $-1,08$ \\
\hline 5 & Reliability & $\begin{array}{l}\text { The accuracy of } \\
\text { recording or } \\
\text { documenting guest } \\
\text { complaints }\end{array}$ & 2,52 & 3,78 & $-1,26$ \\
\hline 6 & Reliability & $\begin{array}{l}\text { Availability of } \\
\text { additional officers in the } \\
\text { event of a very long } \\
\text { queue. }\end{array}$ & & & \\
\hline & & 2,81 & 3,82 & $-1,01$ \\
\hline
\end{tabular}

Table 5 Assurance Aspect

\begin{tabular}{|c|c|c|c|c|c|}
\hline 1 & Assurance & $\begin{array}{l}\text { Guest confidence in the } \\
\text { officer's ability }\end{array}$ & 2,53 & 3,75 & $-1,22$ \\
\hline 2 & Assurance & $\begin{array}{l}\text { Guest confidence in the } \\
\text { solution given by the } \\
\text { officer }\end{array}$ & 2,70 & 3,72 & $-1,02$ \\
\hline 3 & Assurance & Hotel area security & 2,64 & 3,77 & $-1,13$ \\
\hline
\end{tabular}

The tables above show that there are all 27 service quality attributes, which have a negative gap value. Of the 27 attributes, it is known that the attributes of the completeness of supporting facilities have the largest GAP value, namely 1.39 , after that the attribute of the availability of adequate parking spaces with a gap of -1.28 is followed by the attribute of speed of officers responding to guest complaints with a gap of 1.26. This means that the performance of the 27 service quality attributes is still below the expectations of guests of Hotel X Surabaya.

\section{WHATs and HOWs relationship}

At this stage, the relationship between guest needs and the quality of services at Hotel $\mathrm{X}$ Surabaya (WHATs) is determined and the technical responses (HOWs) that have been made. The determination of this relationship is based on the results of discussions with officers at Hotel X Surabaya. The depiction of the relationship between WHATs and HOWs is done with the following symbols.
Symbol $\square$ : 1 there is almost no relationship between technical response and service attributes

Symbol $\Delta$ : 3 weak relationships between technical response and service attributes

Symbol $\bigcirc$ : 5 Medium relationships between technical response and service attributes

Symbol • : 9 Strong relationships between technical response and service attributes

\section{House of Quality}

Making QFD (House of Quality) Matrix Identification of Customer Voices Service quality attributes that have been grouped using factor analysis are used as the main input in QFD analysis as the voice of customers in planning the quality of mathematics laboratory services. The attributes that become the voice of the customer can be seen in the Customer Requirements (WHATs) table.

Formation of the Planning Matrix The planning matrix is an analysis of the voice of customer which includes: guest interest level, service performance, goals and improvement differences, sales points.

\section{CONCLUSION}

From the research that has been done, the following conclusions can be drawn:

From the results of research using service quality and quality function deployment, it can be seen that the services of Hotel X Surabaya which have been carried out so far have not satisfied customers. Although there are several attributes that have felt satisfaction, there are still many service attributes that are not in 
accordance with customer expectations. This can be seen from the value between the level of customer satisfaction and customer expectations, there are 27 service attributes.

Service attributes that really need attention from the hotel to immediately improve the completeness of supporting facilities have the largest GAP value, namely -1.39 after that the attribute of adequate parking space availability with a gap of -1.28 is followed by the attribute speed of officers responding to guest complaints with a gap -1.26 .

Improving the quality of service at Hotel $\mathrm{X}$ Surabaya in accordance with the needs or desires of customers, namely service by prioritizing the improvement of service quality attributes that are needed by these customers.

\section{REFERENCES}

Ariana, Ida Bagus Oka. 2018. Analisis Kualitas Pelayanan Terhadap Nasabah Bank Jatim Cabang X dengan Menggunakan Metode Servqual dan Diagram Fishbone. Undergraduate Thesis Unpublished. Economic $\&$ Business Faculty, Airlangga University, Surabaya.

Arja, Moch. Alex. 2019. Pengaruh Kualitas Produk dan Kualitas Layanan Terhadap Kepuasan Pelanggan dalam membentuk Loyalitas Pelanggan (Studi Kasus pada Laziza Chiken dan Pizza, Sekardangan, Sidoarjo). Under-graduate Thesis Unpublished. Economic \& Business Faculty Nahdlatul Ulama University, Surabaya.

Cohen, L. 2005. Quality Function Deployment: How to Make QFD Work for You. Massachusetts: Addison Wesley Publishing.
Fitria, Asrul, 2019. Pengaruh Kualitas Produk dan Citra Merek Terhadap Minat Beli Konsumen Smartphne Samsung pada Mahasiswa Universitas Nahdlatul Ulama Surabaya. Undergraduate Thesis Unpublished. Economic \& Business faculty Nahdlatul Ulama university Surabaya.

Hakam, M. Fajrul. 2019. Pengaruh Kualitas Produk dan Kualitas Layanan terhadap Loyalitas Pelanggan dengan Kepuasan Pelanggan sebagai Variabel intervening; Studi Kasus pada CV Pustaka Cendikia Jaya. Undergraduate Thesis Unpublished. Economic \& Business Faculty Nahdlatul Ulama University Surabaya.

Heizer, J. and Render, B. 2013. Operations Management: Sustainability and Supply Chain Management. Pearson Higher Ed.

Hoffman, K.D. and Bateson, J.E. 2001. Essentials of Services Marketing: Concepts, Strategies, and Cases. South-Western Pub. Kusumaningtyas, Rizki. 2019. Customer Relationship Management dan Kualitas Pelayanan Pengaruhnya terhadap Loyalitas Pelanggan (SurveI Pada Pelanggan Online Shop Yasshop, Kota Surabaya). Undergraduate Thesis Unpublished. Economic \& Business Faculty Nahdlatul Ulama University Surabaya.

Karya, D. F. 2016. Analisis Kualitas Layanan dan Kepuasan Pengunjung Perpustakaan Kampus A Universitas Nahdlatul Ulama Surabaya (Unusa). Business and Finance Journal, Vol.1, No.2.

Katias Puspandam, Fuji Rahayu. 2018. Analisis Service Quality di Puskesmas X Surabaya dengan Quality Function Deployment. Business and Finance Journal, Vol. 3, No. 2. 
Mahanani, P dan Karya, D.F. 2016. Loyalitas Pasien Rawat Inap Melalui Layanan BPJS Kesehatan (Studi pada RSI Jemursari Surabaya). Business and Finance Journal, Vol. 1, No. 1.

Putri, Resthi Rismarini. 2015. Analisis Perbaikan Kualitas dengan Menggunakan Integrasi Servqual (Service Quality) dan Matriks
Importance Performance Analysis di Perusahaan Forwarding PT Tricipta Semesta. Undergraduate Thesis Unpublished. Economic \& Business Faculty, Airlangga University Surabaya.

Xie, Min., Tan, K.C., \& Goh, T.N. 2003. Advanced QFD Applications. American Society for Quality. Quality Press. 